\title{
Między Portugalią a Francją, między słowem a obrazem - odbiór wielojęzyczności oryginału w przekładzie komiksu Portugal Cyrila Pedrosy
}

Between Portugal and France, between word and image - reception of the original's multilingualism in the translation of Portugal by Cyril Pedrosa

\author{
Agnieszka KRUK \\ Uniwersytet Marii Curie-Skłodowskiej/ Maria Curie-Skłodowska University \\ E-mail: agnieszka.kruk@poczta.umcs.lublin.pl,
}

\begin{abstract}
The purpose of this paper is to find the carriers of strangeness on the level of the text and the image in the Polish translation of Portugal, a comic book written by a French artist Cyril Pedrosa. It also aims to examine how Polish readers identify the multilingual references to the French and Portuguese culture and if they are able to capture all the changes of the setting and the relations between the protagonists. The article studies the advantages and disadvantages of the presence of multilingual elements in the translated text, the problems related to the change of the recipient and resulting from the cultural differences between the readers of the original text and of the translation. It also focuses on how the extra textual information is transmitted through the use of illustrations and colours and whether it is universal or not.
\end{abstract}

Keywords: multilingualism, Translation Studies, comic book, change of recipients, extra textual elements.

\section{Wstęp}

Portugal to powieść graficzna Cyrila Pedrosy, francuskiego twórcy o portugalskich korzeniach, który, bazując na własnych doświadczeniach, ukazuje rozdarcie bohatera między dwoma krajami, językami i kulturami: między Francją, gdzie się urodził i wychował, a Portugalią, skąd pochodzi jego rodzina. Album mówi o kryzysie tożsamości i poszukiwaniu własnych korzeni, porusza również kwestie związane z emigracją. W Polsce komiks doczekał się już dwóch wydań, pierwszego w 2013, a drugiego w 2016 roku. Przekładu dokonał Wojciech Birek.

Powieść graficzna przekazuje kluczowe dla pełnego zrozumienia dzieła informacje zarówno w warstwie tekstowej, jak i poprzez ilustracje. Niektóre z tych elementów są uniwersalne, inne bardziej czytelne dla odbiorców wywodzących się ze wspomnianych kultur lub przynajmniej znających język francuski lub portugalski, jako że akcja komiksu rozgrywa się w różnych regionach Francji i Portugalii. Przy tym zmiany miejsca akcji są dość oczywiste dla francuskiego odbiorcy, ale polskiemu czytelnikowi mogą przysporzyć pewnych trudności w odbiorze utworu. Niniejszy artykuł skupia się na kwestii odbioru wielojęzyczności i wielokulturowości ory- 
ginału przez czytelników przekładu, analizując problemy wynikające ze zmiany odbiorcy poprzez wyodrębnienie nośników obcości na poziomie tekstu i obrazu i zdefiniowanie ich znaczenia dla makrostruktury komiksu. Podejmuje także próbę oceny, na ile polski czytelnik jest w stanie wychwycić wszystkie zmiany miejsca akcji oraz czy i w jaki sposób tłumacz mu w tym pomaga.

Specyfika przekładu Portugal wynika przede wszystkim z silnej obecności elementów tak zwanej ,trzeciej kultury” w utworze. K. Wołek-San Sebastian (2011: 7) definiuje „trzecią kulturę” jako kulturę, ,która nie jest związana ani z tekstem wyjściowym, ani docelowym, a więc zarówno na poziomie oryginału, jak i przekładu jawi się jako zewnętrzna w stosunku do kulturowej matrycy". W tym przypadku będą to wszelkie odniesienia do kultury portugalskiej, obce zarówno francuskim jak i polskim czytelnikom. Obecność tych elementów oznacza, że thumacz od samego początku staje wobec niemożliwości zachowania tej samej reakcji odbiorców, ponieważ francuski czytelnik dostrzega w tekście zestawienie elementów bliskich mu (kultura francuska) i obcych (kultura portugalska), ale nadal w pewnej mierze znajomych ze względu na wywodzenie się z tej samej grupy językowej i względną bliskość geograficzną. Tymczasem polski czytelnik staje wobec elementów obcych (kultura francuska) i ekstremalnie obcych (kultura portugalska).

Aby zrozumieć, na czym polega problem z odbiorem omawianego komiksu, wystarczy przyjrzeć się okładce i kilku pierwszym stronom. Okładka przedstawia widok z balkonu na portugalską ulicę z praniem suszącym się między kamienicami. Tytuł albumu to oczywiście „Portugalia”, a w opisie okładkowym czytamy:

Autor komiksów Simon Muchat cierpi na kryzys twórczy, a jego życie traci sens. Właśnie wtedy zostaje zaproszony do Portugalii, a tam przypadkiem odnajduje to, czego nawet nie szukał: zapach dzieciństwa, melodię wakacyjnych śmiechów, ciepło płynące ze strony zapomnianej, a może nawet utraconej rodziny. Dlaczego Simon nie czuje się związany z żadnym miejscem? Dlaczego kompletnie nie rozumiejąc obcego dla siebie języka portugalskiego, tak mocno reaguje na jego brzmienie? Podczas tej ożywczej podróży czekają na niego odpowiedzi i kolejne pytania. Poznając swoje korzenie, Simon dostaje szansę, by móc wreszcie wyznaczyć własną trajektorię. Jego życie nabiera kolorów.

Kiedy otwieramy komiks widzimy, że pierwsze sceny rozgrywają się na stacji benzynowej, bohaterowie słyszą radiowe reklamy, na ścianach wiszą różne szyldy, później w samochodzie rodzina słucha muzyki. Pytanie brzmi: gdzie toczy się akcja? Czytelnik oryginału otrzymuje co najmniej dziesięć wskazówek, co do miejsca akcji:

- Antar $^{1}$ - nazwa francuskiej sieci stacji benzynowych, widoczna na szyldzie nad stacją i na kontuarze;

- Boissons - francuski napis na ścianie: 'napoje';

- „France Soir”, „France Dimanche”, „Mickey-Parade” - tytuły francuskich gazet i czasopism, widocznych na stacji lub wspomnianych w rozmowie $\mathrm{w}$

\footnotetext{
${ }^{1}$ Strony komiksu nie są numerowane, dlatego przy przykładach nie będą się pojawiały numery stron.
} 
samochodzie;

- Fruité - francuski napój wspomniany w reklamie;

- Platini - francuski piłkarz wspomniany w reklamie;

- Goldorak - francuski tytuł japońskiej bajki, szczególnie popularnej we Francji i w Quebeku, widoczny na dystrybutorze z figurkami (bez pierwszej litery);

- Maxime Le Forestier - francuski piosenkarz, wspomniany w audycji radiowej;

- „Éducation Sentimentale” - tytuł piosenki Maxime’a Le Forestiera, w polskim przekładzie przetłumaczony na „Sentymentalna edukacja”.

Ile spośród wymienionych aluzji dostrzeże i poprawnie zinterpretuje polski czytelnik? Zwłaszcza biorąc pod uwagę, że tytuł komiksu i opis okładkowy wyraźnie sugerują, że akcja będzie się toczyła w Portugalii? Dodatkowo większość tych informacji znajduje się w tle kadrów i nie jest łatwo je odczytać, a nawet jeśli odbiorca zwróci na nie uwagę nie oznacza to jeszcze, że poprawnie zidentyfikuje język, w jakim zostały zapisane. Najbardziej wyraźną wskazówkę stanowi nazwisko francuskiego piłkarza, dużą pomocą byłoby też słowo ,France” w tytułach gazet, ale bardzo trudno jest je odczytać.

Jako że dla polskiego czytelnika większość z wymienionych wyżej wskazówek jest nieczytelna, pewnym rozwiązaniem kompensacyjnym mogłoby być umieszczenie informacji na temat miejsca akcji w przypisie, w ramce w pierwszym kadrze, jak robi się to czasami w filmach, albo w opisie okładkowym. Przy czym informacja w ramce pierwszego kadru stanowiłaby niestety pewne naruszenie formy graficznej komiksu. Tłumacz mógłby również rozważyć wprowadzenie wtrącenia w tekście reklamy albo w radiowych zapowiedziach, np.: „W to upalne francuskie lato Fruité umięśnia mnie” lub „A teraz pora na naszą francuską muzykę z Maxime’em Le Forestiere'em...".

W dalszej części postaramy się pogrupować nośniki obości i elementy wielojęzyczne w tekście i obrazie i wskazać, w jaki sposób ich obecność wpływa na odbiór przekładu.

\section{Idiolekt i polilekt, idiokultura i polikultura}

Aby lepiej zobrazować te zależności warto odnieść się to teorii idiolektu i polilektu oraz idokultury i polikultury. Jak wyjaśnia F. Grucza (1993: 159) ,idiolekt jest językiem (lektem) konkretnej (pojedynczej) osoby, natomiast polilekt językiem (lektem) jakiejś grupy osób"2. Przenosząc tę definicję z kwestii językowych na kwestie zwią-

\footnotetext{
${ }^{2}$ S. Grucza (2010: 43) wyjaśnia, że polilekty (a tym samym polikultury) mogą być rozumiane na dwa sposoby: „Polilekty to logiczna suma lub logiczny przekrój dowolnego zbioru idiolektów, tj. logiczna suma lub przekrój składających się na te idiolekty właściwości wszystkich wziętych pod uwagę osób. Polilekt rozumiany jako logiczna suma to faktycznie wszystkie części zbioru idiolektów wziętych pod uwagę osób, natomiast polilekt rozumiany jako logiczny przekrój to faktycznie tylko wspólne części idiolektów branych pod uwagę podmiotów zbiorowych - wspólnot".
} 
zane z kulturą, możemy mówić o idiokulturze, będącej wiedzą konkretnej osoby na temat kultury, oraz o polikulturze, czyli wiedzy kulturowej jakiejś grupy osób (F. Grucza 2012: 21, 35, R. Utri 2015: 10). Przy czym w naszym przypadku będzie nas interesować nie ogólna idiokultura autora i polikultura odbiorców, a tylko obszar idiokultury i polikultury dotyczący ich wiedzy o Francji i Portugalii. Na gruncie przekładoznawstwa pisał o tym również R. Lewicki, wspominając o ograniczonym bilingwizmie i ograniczonej dwukulturowości odbiorców (R. Lewicki 2002: 49).

Wiedza polskich czytelników na temat francuskiej kultury jest bez wątpienia mniejsza niż wiedza samych Francuzów, jednak mimo wszystko znaczna, ponieważ francuska kultura, jako kultura centralna, jest w dużym stopniu powszechnie znana i rozpoznawalna. Trudniej jest polskim odbiorcom rozpoznać elementy języka i kultury bardziej peryferyjnej Portugalii. Warto zauważyć, że dużą część obcych elementów francuski czytelnik rozpoznaje jako portugalskie na zasadzie prostej opozycji: nie francuskie = portugalskie, podczas gdy polski odbiorca nie może przeprowadzić podobnego rozumowania.

$\mathrm{Z}$ różnic $\mathrm{w}$ obszarach idiolektu i idiokultury autora oraz polilektu i polikultury francuskich i polskich odbiorców wynika odmienne postrzeganie obcych elementów, zwłaszcza elementów trzeciej kultury. Jest to tym bardziej istotne, że właściwie wszystkie wyznaczniki obcości $\mathrm{w}$ analizowanym komiksie pełnią równocześnie w większym lub mniejszym stopniu funkcję wyznaczników miejsca akcji.

Jednymi z najbardziej oczywistych wskazówek dotyczących miejsca akcji są antroponimy i toponimy.

\section{Antroponimy}

Simon i jego francuska rodzina i przyjaciele noszą francuskie imiona, nawet najstarszy stryj ma na imię ,Jacques”, mimo że urodził się jeszcze w Portugalii. Kuzyni z Portugalii i poznani tam ludzie mają oczywiście portugalskie imiona, co ciekawe niekiedy błędnie zapisane: chodzi przede wszystkim o akcenty w portugalskich imionach lub ich brak: „Raúl” (port. Raul), „Julia” (port. Júlia), „Eugenio” (port. Eugénio) etc. Francuski odbiorca $\mathrm{z}$ łatwością odróżni francuskie imiona i nazwiska od imion portugalskich, polski czytelnik musi w tym przypadku bardziej polegać na kontekście wypowiedzi i miejscu akcji.

Dodatkowo w jednej ze scen rodzina jest zaskoczona odkryciem, że ich nazwisko „Muchat” w Portugalii ma formę „Mucha”, co oznacza, że we Francji zostało dostosowane do francuskiej pisowni. Polski odbiorca zauważy co prawda różnicę w pisowni i zdziwienie bohaterów, ale będzie to dla niego pozbawione implikacji.

Poza imionami bohaterów w albumie wspomniane są również znane postacie historyczne, artyści i sportowcy. Ich nazwiska, wymieniane w rozmowach lub w audycjach radiowych, stanowią wskazówki co do czasu i miejsca akcji, kreślą również kontekst historyczny. Jest to istotne szczególnie w pierwszej scenie, która w przeciwieństwie do tego, co sugeruje tytuł albumu, rozgrywa się we Francji, a dodatkowo jest pewnego rodzaju retrospekcją. Kiedy mały Simon jest wraz z rodzicami w drodze do domu dziadków, w radio słychać reklamę napoju Fruité ze sloganem „Gdy Platini zechce pić by pragnienie ugasić wtedy pije Fruité”. Wspomniany francuski 
piłkarz Michel Platini (w oryginale w reklamie pada imię i nazwisko) jest znany również w Polsce, chociaż na pewno nie w takim stopniu jak we Francji. Jego kariera sportowa rozwijała się w latach 1972-1987 - znajomość tego faktu zawęża czas akcji. W kolejnej audycji prezenter wprost mówi, że jest lato '76 a następnie zapowiada utwór Maxime'a Le Forestiera. Nieco dziwi tu decyzja thumacza, aby przełożyć na polski tytuł piosenki: „Sentymentalna edukacja” i jej pierwsze słowa: „Dziś wieczorem...”. Chodzi o utwór „Éducation Sentimentale” z 1972 roku. Artysta nie jest dobrze znany w Polsce, jego piosenka nie może być znana pod polskim tytułem, dlatego prawdopodobnie korzystniejsze byłoby pozostawienie tytułu i słów piosenki w oryginale, aby polski czytelnik miał większą szansę rozpoznać, że jest to utwór francuski. $Z$ drugiej strony być może tłumacz podjął decyzję, że skoro w przekładzie francuscy bohaterowie porozumiewają się po polsku, to w tym samym języku należy oddać francuskojęzyczne utwory. Jak zobaczymy dalej, nie dotyczy to jednak francuskich napisów wpisanych w obraz, więc trudno uznać to za konsekwentną strategię.

Ze znanych Portugalczyków w zasłyszanym na plaży portugalskim dialogu pojawia się nazwisko piłkarza Humberto Coelho, co wyraźnie wskazuje na kolejną retrospekcję, ponieważ Coelho grał w latach 1965-1985, o czym niewielu polskich czytelników będzie wiedziało. Wspomniana retrospekcja rozgrywa się na przestrzeni zaledwie trzech kadrów, więc łatwo ją przeoczyć bez tej dodatkowej wskazówki. Poza tym jedna z poznanych na ulicy kobiet opowiada Simonowi o czasach Salazara, dyktatora, którego nazwisko jest znane również w Polsce, jednak dla francuskich czytelników ma większe znaczenie, ponieważ w czasie jego rządów wzrosła liczba Portugalczyków emigrujących właśnie do Francji, o czym opowiada spotkana kobieta. Wspomina również innego portugalskiego polityka, mówiąc, że „co do rewolucji, to Soares zgarnął wszystkie zaszczyty...”.

\section{Toponimy}

Łatwo rozpoznawalne miejsca to z pewnością Paryż i Lizbona. We Francji Simon wybiera się również na wesele kuzynki do Moulin w Burgundii, jak zostaje uściślone w dialogu „w okolicach Beaune”, „co najmniej pięćset kilosów” od Paryża. Jego ojciec opowiada również o dzieciństwie w Gralens, wspomina też Albi i Tarn. Dodatkową informacją jest znak drogowy na skrzyżowaniu w wiejskiej okolicy, wskazujący drogę do Albi i w drugą stronę do Gralens, co sugeruje, że są to dwie niewielkie miejscowości leżące niedaleko siebie. A zatem obraz doskonale uzupełnia tu nieco chaotyczne informacje podane przez bohaterów.

Kolejnym francuskim miejscem wspomnianym w komiksie jest „lotnisko w Orly”, co wygląda na dosłowne thumaczenie, podczas gdy nazwa lotniska funkcjonująca w Polsce to lotnisko Paryż-Orly. Drugie wspomniane francuskie lotnisko to bardziej znane „Roissy Charles de Gaulle” - tu również dla polskiego czytelnika jaśniejszy byłby obowiązujący w Polsce zapis lotnisko Paryż-Roissy-Charles de Gaulle, choćby ze względu na to, że w obu przypadkach w nazwie pojawiłoby się słowo „Paryż”, co ułatwiłby ich zlokalizowanie. 
Zmiana miejsca akcji następuje, gdy Simon wybiera się do Portugalii na festiwal komiksu. Ląduje na lotnisku w Lizbonie, ale jego hotel znajduje się w Costa de Caparica, około $15 \mathrm{~km}$ od Lizbony, tam też odbywa się festiwal. Co ciekawe, nazwa tego miasta nie jest wymieniona $\mathrm{w}$ dialogach, a wpisana $\mathrm{w}$ obrazki: pojawia się na plakacie na ścianie hotelu, gdzie może zostać wzięta za reklamę, a następnie na przystanku autobusowym, a zatem z łatwością można ją przeoczyć.

Podczas drugiej wizyty bohater odwiedza portugalską część rodziny. Pokazując mu hodowane na balkonie rośliny, kuzyn mówi: „Tu jest Bairro Alto, blisko stąd to centrum Lizbony". Ani francuskim, ani polskim czytelnikom nie wyjaśnia co prawda, że Bairro Alto jest jedną z dzielnic miasta, ale można się tego w pewnym stopniu domyślić. Po krótkim pobycie w stolicy Simon wybiera się do starego domu rodzinnego w Marinha da Costa, jak wyjaśnia kuzyn nie jest to daleko, „godzina samochodem". W innym miejscu, wspominając tę miejscowość, stryj Simona mówi o załatwieniu formalności związanych z dokumentami „w merostwie Marinha da Costa”, co jest błędem autora zachowanym w thumaczeniu, ponieważ merostwa są francuskimi urzędami. Być może w oryginale jest to błąd zamierzony, jako że stryj w rozmowie z francuską rodziną mógł świadomie posługiwać się nazwami urzędów, jakie są im znane, trudno to natomiast uzasadnić w polskim tekście. Ostatnim miejscem w Portugalii wspomnianym w komiksie jest region Alentejo.

Wyznaczniki obcości $\mathrm{w}$ odniesieniu do miejsc pojawiają się również na poziomie obrazu: portugalskie ulice różnią się od francuskich, są bardziej nasłonecznione, węższe, suszy się nad nimi pranie. W Lizbonie można nawet dostrzec różnice wysokości między ulicami, tak charakterystyczne dla tego położonego na wzgórzach miasta.

Jak widać sam autor zręcznie wyjaśnia czytelnikom położenie wspomnianych przez siebie miejsc, na przykład poprzez podanie w dialogach odległości między nimi, zwłaszcza w przypadku portugalskich miejscowości, obcych nawet dla francuskich odbiorców. Oszczędza to tłumaczowi trudu umieszczania w tekście lub poza tekstem dodatkowych wyjaśnień. Jednak należy podkreślić, że wszystkie te miejscowości i ich opisy zazwyczaj są zaledwie wspominane w dialogach lub pojawiają się wpisane w obraz, a kolejne informacje o nich są rozrzucone na przestrzeni kilku - kilkunastu stron. Do tego bohaterowie często zmieniają miejsce pobytu, dlatego czytelnikowi nie jest łatwo wychwycić wszystkie te zmiany opierając się jedynie na tych fragmentarycznych informacjach. Dlatego też ponownie możliwą strategią kompensacyjną byłoby umieszczenie $\mathrm{w}$ thumaczeniu dodatkowych informacji na temat miejsca akcji.

\section{Tekst wpisany w obraz}

Tekst wpisany w obraz to w komiksie wszelkiego rodzaju szyldy, plakaty, drogowskazy, znaki czy ogłoszenia, pojawiające się zazwyczaj w tle. Już na pierwszej stronie komiksu pojawia się stacja benzynowa z szyldem „Antar”. Antar to nieistniejąca już francuska sieć stacji benzynowych, zatem nazwa stacji wskazuje zarówno na miejsce, jak i czas akcji, jednak jest czytelna jedynie dla francuskich odbiorców. Od pierwszej strony wskazuje, że mimo tytułu, miejscem akcji jest początkowo 
Francja. Kolejne wskazówki pojawiają się na następnych stronach: oprócz wspomnianej już reklamy Fruité na stacji widać regał z napojami oznaczony „boissons” oraz tytuły francuskich gazet.

Gdy kończy się pierwsza retrospekcja, akcja przenosi się do współczesności, do banku. Na ścianie znajduje się duży plakat z datą 2002 i tekstem (częściowo zasłoniętym przez dymki i postacie): „Rentrez (...) l'ère (...) avec le Crédit Populaire” - francuski czytelnik z łatwością rozpozna tu tekst w jego ojczystym języku, podczas gdy polski odbiorca prawdopodobnie zignoruje go jako niezrozumiałe tło. Tym samym początkowo nie będzie miał pewności, czy akcja toczy się nadal we Francji, czy już w sugerowanej przez tytuł Portugalii.

W kolejnych scenach we Francji na ulicach widać szyldy, takie jak „École elementaire" - 'szkoła podstawowa', „gare" - 'dworzec', „restaurant" - 'restauracja', „fromage” - 'ser', „café” - 'kawiarnia', „boulan...” (pełne słowo „boulangerie” nie zmieściło się w kadrze) - 'piekarnia'.

W częściach poświęconych Portugalii obrazki pokazują często szersze kadry, aby jak najdokładniej oddać klimat portugalskich ulic. Stąd też pojawia się więcej portugalskich szyldów. Podobnie jak w przypadku omówionego dalej zabiegu umieszczania $\mathrm{w}$ tle całych portugalskich wypowiedzi lub dialogów, wydaje się to służyć lepszemu oddaniu klimatu tych miejsc. Co prawda czytelnik prawdopodobnie nie będzie $\mathrm{w}$ stanie ich odczytać ze zrozumieniem, jednak nie byłby również $\mathrm{w}$ stanie ich zrozumieć, gdyby jak Simon nagle znalazł się na portugalskiej ulicy. Tak więc portugalskie szyldy i dialogi niekoniecznie mają wartość informacyjną, bardziej niż o ich treść chodzi o wywołanie pewnego wrażenia zanurzenia się w portugalskiej codzienności. Przykładowe portugalskie szyldy to: „sapateiro” - 'szewc', „padaria” - 'piekarnia', „pastelaria” - 'cukiernia' itp. Inne przykłady tekstu wpisanego $\mathrm{w}$ obraz to tablica $\mathrm{z}$ cenami produktów w barze na plaży: „sandes, caracóis, torradas" - 'kanapki, ślimaki, grzanki', plakat w hotelu, mapa okolic Lizbony na przystanku autobusowym, etykiety na produktach spożywczych.

Wielojęzyczne szyldy u czytelników oryginału wywołują dwie odmienne reakcje: francuskie napisy wyglądają swojsko i mają wartość informacyjną, wskazując na miejsce akcji, natomiast portugalskie szyldy mają za zadanie wywołać wrażenie obcości i zanurzenia w odmiennej kulturze. One również wskazują na miejsce akcji, ale nie poprzez ich wartość informacyjną, a na zasadzie opozycji „nie francuskie, a zatem portugalskie". W polskim przekładzie żaden z francuskich i portugalskich szyldów nie został przetłumaczony, dzięki czemu z jednej strony zachowały one znamiona obcości, ale z drugiej polskiemu odbiorcy trudno jest odróżnić obce francuskie napisy od równie obcych napisów portugalskich, wszystkie są dla niego jednakowo niezrozumiałe.

O. Wojtasiewicz (2005: 81-85) nazywa obcojęzyczne wtręty „,aluzjami językowymi”, a K. Hejwowski (2010: 48-54) wyróżnia osiem technik thumaczenia aluzji językowych: transfer, transkrypcja, neutralizacja, ekwiwalent funkcjonalny, stylizacja (podstandardowa, wiejska, miejska, kolokwialna, slangowa, archaiczna), relatywizacja, opuszczenie, komentarz od tłumacza (w tekście lub w paratekście). 
W przypadku napisów wpisanych w obraz tłumacz konsekwentnie stosuje technikę transferu, co ciekawe nie tylko w przypadku portugalskich wtrętów, ale także przy francuskich szyldach i plakatach. W całym albumie pojawia się tylko jeden komentarz od thumacza: w scenie przed szkoła jeden z rodziców mówi, że jego dziecko ,jest w CE2”, a w przypisie thumacz wyjaśnia, że jest to „druga klasa kursu elementarnego, obejmująca trzeci rok nauki w szkole podstawowej”. Biorąc pod uwagę, że jest to jedynie dialog zasłyszany na ulicy, nie wnoszący nic do akcji, być może wystarczyłaby umieszczona w samym dymku informacja, że dziecko jest $\mathrm{w}$ trzeciej klasie. W każdym razie samo użycie w tym miejscu przypisu stanowi precedens wskazujący, że w innych miejscach przypisy również byłyby dopuszczalne, mimo że lekko naruszają kompozycję graficzną komiksu. Byłyby uzasadnione zwłaszcza w miejscach, gdzie mogłyby pomóc zauważyć zmiany miejsca akcji.

\section{Obcojęzyczne dialogi}

Wspomniane już obcojęzyczne dialogi występują w komiksie w różnorodnych postaciach: od topornego lapsolektu ${ }^{3}$ babki Simona, kiedy stara się mówić po francusku, przez bardziej poprawne francuskie wypowiedzi jego kuzyna, okraszone portugalskimi wtrąceniami, toczące się w tle portugalskie rozmowy, aż po nieudolne próby mówienie po portugalsku, podejmowane $\mathrm{z}$ coraz większą determinacją przez głównego bohatera. Naturalnie wszystkie francuskie wypowiedzi są oddane po polsku, w przypadku osób słabo znających język francuski w polskim thumaczeniu pojawiają się zamierzone błędy, jak kiedy babka Simona żali się, że rodzina za rzadko ją odwiedza. W oryginale czytamy:

- Não percebo por que é que não ficam alguns dias...

- Parle en français, Maman, Martine ne comprend pas bien...

- Aaaah... En français, en français... 'Ta bem... Dé toute façon, ça né sert à rien, vous faites bien comme vous voulez. (...) Oune pauvre vieille dé mierda... C'est tout cé qué jé suis! Miséééria...

- Ahem... tu reveux du café, Maman?

- Jé veux bien... Heureusement qué jé t'ai, mon pétit Jacques...

W polskiej wersji:

- Não percebo por que é que não ficam alguns dias...

- Mów po francusku, mamo, Martine nie rozumie za dobrze...

- Aaaah... po fransuszku, po fransuszku... 'Ta bem... Tak szy owak, to nis nie da, srobisie so sechsesie. (...) Biedna starucha de mierda... Tym własznie jestem! Miséééria...

- Eheem... Dolać mamusi jeszcze kawy?

- Poprosze... Dobsze, że mam szebie, mój mały Jacques...

W oryginale lapsolekt babci, kiedy ta mówi po francusku, charakteryzuje się przede wszystkim bardziej otwartymi samogłoskami. Byłoby to niemożliwe do oddania w ten sam sposób w polskim tłumaczeniu - jako że w naszym języku trudno

\footnotetext{
${ }^{3}$ A. Pieczyńska-Sulik (2005: 179) definiuje lapsolekt jako „łamaną odmianę językową”, używaną przez postaci, które popełniają błędy posługując się językiem obcym.
} 
mówić o otwartych i zamkniętych samogłoskach, zapisanie ich z akcentem niewiele by znaczyło dla polskiego odbiorcy. Dlatego też tłumacz skupia się na innej charakterystyce języka portugalskiego, a mianowicie na tym, że dla słuchacza wydaje się to być język „,szeleszczący”, w którym używa się dużo głoski „sz”, brakuje natomiast głoski „c". Według klasyfikacji Hejwowskiego jest to sylizacja podstandardowa, której funkcją jest ukazanie obcego pochodzenia postaci i słabej znajomości języka (K. Hejwowski 2010: 46). Zostało to dobrze oddane w polskim zapisie, chociaż chwilami nieco przejaskrawione, przez co zaczyna przypominać mowę osób pod wpływem alkoholu (,srobisie so sechsesie”).

Co ciekawe wtrącone słowo mierda - 'gówno' nie jest słowem portugalskim, a hiszpańskim. Również zapis portugalskiego pytania nie jest poprawny, zaimek pytający por que - 'dlaczego' powinnien być zapisany łącznie. Te błędy pokazują, że portugalski idiolekt Pedrosy nie jest zbyt rozwinięty. Polski tumacz nie poprawia ich.

Francuski kuzyna Alessandro jest już o wiele bardziej poprawny niż lapsolekt babci, wyróżniają go jednak portugalskie wtrącenia: „Sim” - 'tak', „não” - 'nie', „'ta bem?” - 'dobrze?', „como se diz”? - 'jak to się mówi?'. Ich znaczenie można $\mathrm{z}$ łatwością wywnioskować z kontekstu.

Poza tym, gdy Simon spaceruje po portugalskich ulicach, słyszy wokół dużo fragmentów portugalskich rozmów. Są one oznaczone innym, przeważnie ciepłym kolorem dymków. Podobnie jak w przypadku szyldów, ich znaczenie nie jest tak naprawdę istotne, widać jednak, że bohater rozkoszuje się ich brzmieniem, wywabiają go one na ulicę, próbuje się nauczyć kilku słów i wyrażeń. Język portugalski jest dla niego co prawda zrozumiały jedynie w niewielkim stopniu, jednak widać, że wywiera na nim pozytywne wrażenie. Chociaż czytelnik prawdopodobnie nie zna języka portugalskiego, może nawet jego brzmienia, odniesie podobne wrażenie dzięki oddanej przez obraz mimice Simona, jego zachowaniu oraz ciepłej kolorystyce rysunków. Ten pozytywny stosunek do języka portugalskiego został również wyrażony w bezpośrednim komentarzu bohatera: „mówią w tym języku, takim czułym, takim łagodnym".

\section{Elementy kulturowe}

Kolejnymi wyznacznikami obcości są elementy kulturowe, tradycje, zwyczaje, a nawet zachowania. We Francji jest to pétanque, czyli gra w bule, tradycyjna francuska gra towarzyska $\mathrm{z}$ elementami zręcznościowymi. Nazwa gry nie zostaje wymieniona $\mathrm{w}$ tekście, można ją rozpoznać po obrazkach i po części po wzmiankach w dialogach graczy: „6:5 dla was”, „wybij tę, która nam przeszkadza, tam, po prawej”, „tak, bierze”. Dla francuskiego odbiorcy są to wystarczające informacje. Polski czytelnik, nawet jeśli nie zna nazwy gry i jej zasad, będzie miał o niej ogólne pojęcia dzięki ilustracjom i dialogom.

Portugalskie zwyczaje są zazwyczaj dokładniej objaśniane. Jako że Simon jest Francuzem, są one dla niego obce, podobnie jak dla francuskich odbiorców, dlatego wszystkie wyjaśnienia udzielane bohaterowi pozwalają autorowi na naturalne wythumaczenie obcych elementów ogółowi czytelników, tak francuskich, jak i innych 
narodowości. Objaśnienia te nie są strategią thumacza, ale samego autora, np. kiedy przy wspólnym obiedzie siedząca obok Simona kobieta thumaczy mu, jak w Portugalii je się sardynki: nie widelcem, a położone na chlebie. Przy tym w wersji tekstowej pojawia się tylko zakaz: „Nie, nie, nie widelcem!” i ogólny wstęp do instrukcji: „Widzisz... Tak właśnie trzeba jeść sardynki!”, natomiast właściwe wyjaśnienie sposobu ich spożywania wyrażone jest poprzez ilustracje. W podobny sposób, używając tekstu i obrazu, opisane są obchody Nocy Świętojańskiej, kiedy Portugalczycy „okładają się po głowach młotami. Przez ten symboliczny gest każdy wyraża żal za popełnione świństwa i obiecuje sobie przebudzić się z powszechnego odrętwienia w nadchodzącym roku". To akurat nie jest najlepszy opis, ponieważ brakuje informacji, że są to niegroźne plastikowe młotki, podczas gdy zarówno przytoczony fragment, jak i ilustracje sugerują, że są to duże, potencjalnie niebezpieczne „młoty". Trudno ocenić czy wynika to z nieznajomości opisywanej tradycji przez autora czy z jego chęci podkreślenia, jak dziwna się ona wydaje.

W pewnym stopniu różnice między oboma krajami są ukazane także poprzez relacje czy sposób bycia bohaterów. Co prawda trudno ocenić na ile jest to cecha wspólna wszystkich Francuzów i Portugalczyków, a na ile specyficzne relacje między członkami opisywanej rodziny, jednak nie da się nie zauważyć, że we Francji stosunki rodzinne są chłodniejsze i pełne napięć, podczas gdy w Portugalii Simon zostaje przyjęty z otwartymi ramionami, choć nie należy do najbliższej rodziny. Ta otwartość Portugalczyków wyrażona jest również przez ciepłe, jasne kolory, podczas gdy we Francji sceny rodzinne rozgrywają się przeważnie w nocy, w dość ponurej kolorystyce, co równocześnie odzwierciedla uczucia bohaterów. Dobór kolorystyki jest uniwersalny, łatwy do odczytania dla każdego odbiorcy. Nieco trudniej wychwycić różnice w zachowaniu, na przykład otwartość Portugalczyków wyrażoną tym, że dzielą się z Simonem jedzeniem (wręcz w nadmiarze) i pozwalają mu się zatrzymać w starym domu rodzinnym. Kuzyn odwozi go na miejsce, przy czym znacznie wydłuża podróż, zatrzymując się, aby odwiedzić przyjaciół, napić się kawy i zjeść „pasteis de nata”, (poprawnie: „pastéis”), tradycyjne portugalskie ciastka z kremem, które jednak nie zostały ani bliżej opisane, ani ukazane na ilustracji. Simon poznaje też sąsiadów, z wieloma nawiązuje kontakty, wszyscy wydają się znać nawzajem - życie w Portugalii jest odmienne niż jego życie we Francji. Różnice w zachowaniu postaci można wythumaczyć również tym, że we Francji Simon mieszkał w wielkim mieście, a w Portugalii zatrzymuje się w małej miejscowości, jednak tak dla Francuzów, jak i dla Polaków, będą one również odzwierciedleniem przekonania, że mieszkańcy Półwyspu Iberyjskiego są ludźmi o wiele bardziej otwartymi niż inni Europejczycy.

\section{Konkluzje}

Jak pokazuje analiza wybranych przykładów, wyznaczniki obcości w komiksie pojawiają się zarówno na poziomie tekstu, jak i obrazu: w nazwach i ilustracjach miejsc i postaci, napisach wpisanych w obraz, różnojęzycznych dialogach i odniesieniach kulturowych. Większość z nich wyraźnie wpływa na makrostrukturę tekstu, określając miejsce i czas akcji, relacje między bohaterami i ich emocje. Nie wszyst- 
kie są jednakowo czytelne dla odbiorców wywodzących się z różnych kultur: francuski czytelnik z o wiele większą łatwością zauważy, które sceny rozgrywają się we Francji, a które w Portugalii, podczas gdy dla polskiego odbiorcy wszystkie obce elementy mogą się ze sobą zlewać. Bez dodatkowych wyjaśnień ze strony thumacza pewne odniesienia mogą przez to zostać niepoprawnie odczytane, dlatego tłumacz powinien zastanowić się, czy bardziej istotne jest dla niego zachowanie niezmienionej formy graficznej komiksu, czy też ukazanie czytelnikowi do jakich kultur i języków odnoszą się występujące w tekście nośniki obcości.

R. Lewicki (2002: 46) zauważa, że „przekład należy uznać za zjawisko kultury” oraz że może być postrzegany jako „dokument recepcji odmienności kulturowej” Portugalia Pedrosy jest tego doskonałym przykładem, ponieważ już tekst oryginału łączy elementy dwóch kultur, a jego przekład daje polskim czytelnikom możliwość dostępu do „nowego, kompleksowego tekstu kultury” (R. Lewicki 2002: 46). W polskim przekładzie czytelnik natrafia na wiele obcych elementów pochodzących $\mathrm{z}$ dwóch różnych kultur i języków, co może prowadzić do niezrozumienia, a nawet irytacji. Jednak jak zauważa Lewicki (2002: 47-48) reakcja odbiorcy będzie zależała od jego uwrażliwienia na obcość jako kategorię kultury: dla czytelników, którzy akceptują możliwość wystąpienia obcych elementów w przekładzie, elementy te nie będą się wydawały irytujące, ale będą stanowiły pewną wartość tekstu. Dlatego też jeśli odbiorca sięgający po Portugalię będzie świadom, że natrafi w komiksie na elementy przemieszanych ze sobą obcych mu kultur i języków, to właśnie ta możliwość międzykulturowego spojrzenia na kwestie związane z emigracją i poszukiwaniem własnych korzeni będzie dla niego niezaprzeczalnym atutem tego albumu.

\section{Bibliografia}

Grucza, F. (1993), Język, ludzkie właściwości językowe, językowa zdolność ludzi, (w:) J. Piontka/ A. Wiercińska (red.), Człowiek w perspektywie ujęć biokulturowych. Poznań, 151-174.

Grucza, F. (2012), Antropocentryczna a paradygmatyczna (tradycyjna) lingwistyka (stosowana) i kulturologia (stosowana), (w:) „Lingwistyka Stosowana/ Applied Linguistics/ Angewandte Linguistik" 6, 5-43.

Grucza, S. (2010), Główne tezy antropocentrycznej teorii języków, (w:) „Lingwistyka Stosowana/ Applied Linguistics/ Angewandte Linguistik" 2, 41-68.

Hejwowski, K. (2010), O tlumaczeniu aluzji językowych, (w:) R. Lewicki (red.), Przekład. Język. Kultura. t.2. Lublin, 42-56.

Lewicki, R. (2002), Obcość w przekładzie a obcość w kulturze, (w:) R. Lewicki (red.), Przekład. Język. Kultura. Lublin, 43-51.

Pedrosa, C. (2011), Portugal. Charleroi.

Pedrosa, C. (2016), Portugalia. Warszawa.

Pieczyńska-Sulik, A. (2005), O językowo-kulturowych uwarunkowaniach (nie)przektadalności lapsolektu, (w:) K. Hejwowski (red.), Kulturowe i językowe źródła nieprzekładalności. Olecko, 179-185. 
Utri, R. (2015), The translator and his/her language/culture, (w:) J. Brzozowski/ A. Jastrzębska (red.), Między Oryginałem a Przekładem: Obcość kulturowa w przekładzie, 2(28), r. XXI. Kraków, 9-25.

Wojtasiewicz, O. (2005), Wstep do teorii thumaczenia. Warszawa.

Wołek-San Sebastian, K. (2011), ,Trzecia kultura” a problemy przektadu nowszej literatury chorwackiej. Kraków. 